\title{
Minimum Marriage Age: Study of Fiqh of Four Madhabs
}

\author{
Maisarah $^{1}$, Afrizal $^{1}$, Zulfahmi $^{1}$, Fizal Mauliza ${ }^{2}$, Faisal Murni ${ }^{2}$ \\ ${ }^{1}$ Lecturer in Islamic Institute of Al-Aziziyah Samalanga, Bireun Aceh, Indonesia \\ ${ }^{2}$ Student in Islamic Institute of Al-Aziziyah Samalanga, Bireun Aceh, Indonesia \\ Email: maisarahmuhammad6944@gmail.com
}

\begin{abstract}
:
Figh of four madhab (Hanafi, Maliki, Shafi'i and Hambali) permit the marriage of minors, so that parents tend to marry their children at an underage. This ppinion is criticized in modern times who want a minimum age of marriage. The question arises how the interpretation of the four madhab (Islamic jurisprudence) of thought is used and are there other arguments that can be used in reinterpreting the existence of a minimum age of marriage. This study uses some methods, firstly, to examine the verses and hadith to find out whether there are cues about the minimum age of marriage or not. Secondly, to reinterpret using the ta'liliyyah method and the termiyyah of the arguments used by the religious and contemporary scholars. The result shows that the madhab declares Surah al-Thalaq as the proposition regarding the ability of marriages of young children. According to the author, the logic is incorrect because there is no need to iddah for virgin women contained in Surah al-Ahzhab verse 49; The religious scholars also use it as the proposition of the Prophet's marriage hadith. with 'Aisha r.a when she was a child, even though this incident occurred in Mecca before the Muslim period and before the hadith about the guardian's obligation to ask permission for a girl or widow. This study also finds other verses that can be used as arguments in limiting the age of marriage, namely Surat al-Nisa 'verses 5-6 and 9, the hadith of Ibn Mas'ud and maslahah to be achieved from a marriage, which explicitly states that both adult and maturity both physically and mentally as a condition of marriage.
\end{abstract}

Keywords :

age; marriage; figh; madhab

\section{Introduction}

Marriage is prescribed by religion because it is one of the efforts to preserve the glory of the offspring and is a key to the peace of society. However, a noble task may not achieve the target, if the control is held by people who do not deserve it, including household development. Because the consequences of a marriage will lead to mutual rights and obligations between husband and wife. The existence of rights and obligations of husband and wife implies that the holders of responsibilities and rights of obligations have maturity both physically and mentally.

The above description shows that the maturity factor is a very important condition, although it is not included in the pillars and conditions of marriage. The four schools do not explicitly set certain age limits for men and women to carry out marriages, instead there is a statement: "permissible marriage between men and women who are still small", even mentioned directly where each book of fiqh mentions the authority of guardians mujbir to marry young children and virgins. ${ }^{1}$ The legal conclusions above, are caused because there are no verses in the Koran that clearly state the age limit of marriage and there is no hadith of the Prophet. which expressly states so, is also based on the fact of the marriage of the Prophet. with 'Aisyah r.a who at that time was still a child (6 years old).

${ }^{1}$ Al-Jaziri, Kitab al-Fiqh 'alā al-Madhāhib al-'Arba'ah, Juz IV, (Mesir: Dar al-Manaar, 1999), p. 216 
In Indonesia, the case of underage marriage is not a new problem. The causes also vary, ranging from economic factors, lack of education, shallow understanding of culture and certain religious doctrines, to the factor of pregnancy that occurs. Along with the times, people's perceptions have changed otherwise. The marriage of girls at a young age becomes taboo and is considered to eliminate the future of children, the model of marriage also has the potential to shake social harmony, because in it there is violence, child trafficking and pedophilia crime. On the other hand marriage at a young age is considered to be able to minimize adultery among adolescents, due to the rapid development of the information world. ${ }^{2}$ Until now there is still a lot of controversy about underage marriage in this country, because there are so many views and impacts that are more negative, although no positive impacts are denied.

Literature of figh of four madhab (Islamic jurisprudence) do not adhere to the concept of the minimum age of marriage. However, this statement is difficult to maintain today. This is proven, Indonesia itself is known as adherents of the school has begun to ignore it. UndangUndang Perkawinan (marriage law) No. 1 of 1974 and the Kompilasi Hukum Islam (KHI), for example, set a minimum age of 19 years for men and 16 years for women. Referring to the rationale behind the provisions on the age of marriage in both the Undang-Undang Perkawinan (UUP) and KHI heavier on the consideration of biological aspects, this consideration contains its own weaknesses, especially when related to women's reproductive health. Data from Badan Koordinasi Keluarga Berencana Nasional (State Ministry for Population) states "maternal mortality in Indonesia, one of the triggers is the age of marriage for women, 16 years who are considered too young". ${ }^{3}$

Seeing the above facts it can be understood that the more open possibilities towards the formulation of new marital age restrictions (maturity of marriage age) in accordance with the sociological and cultural conditions of a place. Indeed there is no explicit reference to the Qur'an or the hadith of the Prophet. regarding the age limit of marriage, but there are a number of verses and hadith that indirectly signal it as in Surah al-Nisa 'verse 6. It appears that the management of assets is implied to be for those who are already baligh (mature) and rusyd (maturity).

The bond of marriage is more complex because it is burdened with greater responsibilities than managing property. Seeing rights and obligations is an absolute implication of a marriage bond, then the Kabirah marriage itself can lead to mudharah matters let alone saghirah marriage. Related to the preconditions of maturity strengthened by the narration of the history of Ibn Masud who advocated marriage for young people who already have the ability to do so. If this opinion is fully accepted, it will no doubt have broad implications for the fiqh of munakahah, especially the four schools to ward off a series of underage child marriages. With the above considerations, this problem is interesting to be investigated further.

The main problem to be studied about How the propositions, arguments, and interpretations of the four schools about the minimum age of marriage; How is the interpretation of the four schools of teachings on the Qur-an Surah Al-Nisa verse 6; Is there an argument that can be used to support the existence of a minimum marriage age and can be reinterpreted the age of marriage for the present context. So, this study aims to find out Knowing and explaining the arguments used by four madhabs of law in determining the presence or absence of marriage age restrictions and ways of understanding them; Knowing and explaining their interpretation of the

\footnotetext{
${ }^{2}$ Muhammad Fauzi Adhim, Indahnya Pernikahn Dini, (Jakarta: Gema Insani Press), pp. 1-2

${ }^{3}$ Kompas, edition 8 April 2001
} 
Koran surah al-Nisa 'verse 6; Know and explain the opportunities for reinterpretation of the age of marriage by using the method of ushul fiqh.

\section{Literature Review}

A new marriage is considered valid if it is perfectly harmonious and the conditions. If one of the pillars or conditions is not fulfilled, the marriage becomes null and void. The four madhabs demand that all conditions and harmony must be fulfilled in a marriage. One of the conditions that must be fulfilled by parties who wish to carry out marriages according to the madhab of Hanafi is the pleasure (not feeling forced) of the bride and groom. ${ }^{4}$ The emergence of willingness is inseparable from the understanding of the wali mujbir, because the wali mujbir is believed to be able to guarantee that his ijbar rights are solely based on sincere compassion and care. Wali mujbir is the party that can approve (not need permission or prior approval) to carry out marriages of people who are under his guardianship. ${ }^{5}$

Fuqaha' differ in opinion about the right of ijbar for the guardian in marriage. This difference occurs because they differ in formulating marriage guardians. Jumhur established ijbar rights and the madhab of Hanafi rejected it based on a hadith of the Prophet. which mean:

"Do not be married to a widow so her opinion is asked and not to be married to a girl so her approval (permission) is asked. Friends ask: yes Rasul Saw. how is the permission? Rasul Saw. said: if he is silent "( HR. Bukhari dan Muslim).

Said the girl in the hadith above is a Jariyah who is still a virgin. Another argument used by both the jumhur and the madhab of Hanafi is the hadith of Muslim history, which means:

"A widow woman has more rights over herself than her guardian, while a girl must be heard by her consent, and that silence is her agreement" (HR. Muslim).

Both groups both jumhur and madhab of Hanafi use the same hadith, but with different understandings, especially in determining illat contained in the hadith. Differences occur because lafadh 'amar is understood by mustahab (not mandatory orders). Jumhur argues that his illat is because the sentence is distinguished between biker (girl) and tsayyib (widow). ${ }^{6}$ Jumhur said asking for a girl's approval was not a mandatory order (mustahab). ${ }^{7}$ Because in this hadith the widow and the girl are distinguished. So that the marriage of a girl carried out by a guardian without asking permission for a girl is legitimate and innocent. Because if the father cannot marry without the girl's permission, then it is as if the girl is no different from a widow. Even though this hadith clearly distinguishes widows and girls. Widows must clearly state their permission. Meanwhile, a girl is quite silent.

Jumhur logic is like ignoring lafadh tusta'dhan contained in the hadith, whereas lafadh 'amar shows the command (fard). The two hadiths require permission for girls, what is distinguished is

\footnotetext{
${ }^{4}$ Husein Muhammad, Fiqh Perempuan, Refleksi Kiai Atas Wacana Agama dan Gender, (Yokyakarta: LKIS Pelangi Aksara, 2007), p. 105

${ }^{5}$ Sayyid Sabiq, Fiqh al-Sunnah, Juz. II, (Madinah: al-Fath li ‘llām al-‘Arabiy, 1990), p. 27

${ }^{6}$ Al-Sarakhsy, Usul al-Sarakhsy, Juz II, (Beirut: Dar al-Kutub al-IImiyyah, 1983), p. 349

${ }^{7}$ Al-Syafi'i, al- Ūmm Juz IV, (Beirut: Dar al-Kitab al-IImiyyah, 1993), p. 29
} 
the way to answer from women. In dalalah isyarah two of the above hadith shows the position of women have reached baligh, where their permission can be accounted for.

\section{Discussion}

A marriage hadith 'Aisha who was used as a proposition allowed a father to marry his young daughter without asking permission, with the reason not to mention permission requests. According to al-'Asqalani, the evidence was clear, and even implied that it happened before the decree was issued to ask permission from women who were still girls because the story of Aisha's marriage took place in Mecca and before the Prophet. emigrate. ${ }^{8}$ Rasullullah Saw Marriage where 'Aisha took place in Mecca and was the period before Tasyri'.

\subsection{Marriageable Age and Evidence Used by Four Madhabs}

According to the four madhabs all ages can carry out marriage. Therefore, from a number of classical books there is the term marriage al-saghir / al-saghirah (male / female who is not yet mature). The term commonly used in fiqh science to refer to the arrival of the maturity phase is baligh. The measure used as a marker of baligh for children is a "nocturnal emission" (bulum), as stated in surah al-Nur verse 59. All four madhabs agree, nocturnal emission is the clearest indicator that a boy and a girl have reached taklif stage ( required to run religious law). Specifically for the maturity phase of the girl, besides being marked by wet dreams, it is also identified by her menstruation or pregnancy. However, they differ in their opinions in estimating the age limit of maturity based on age, when a person becomes a Muslim (religious burden).

The difference between the madhabs regarding the age limit of baligh, is because there are differences in using istinbat ahkam (excavation methodology or legal interpretation). Besides being influenced by the environment and culture where they live.

The four madhabs agreed in allowing saghirah marriage, or in a more popular term referred to as underage marriage. According to them, for marriages the issue of baligh and sensible criteria is not a requirement for its validity. Some of the arguments put forward include:

\section{a. Al-Qur'an Surah Al-Thalaq verse 4}

"And women who are no longer menstruating (menopause) among your women if you doubt (about their iddah), then their iddah is three months; and so (also) women who are not menstruating ..."

It has been narrated, that a people between Ubay Ibn $\mathrm{Ka}^{\text {'ab }}$ and Khalad Ibn $\mathrm{Nu}^{\text {'man, }}$ when he heard the word of Allah. Surah al-Baqarah verse 228, they asked, "O Messenger of Allah., What about $i d d a h$ wives who do not have quru both children and old people? Then the verse alThalaq verse 4 came down. ${ }^{9}$ The Madhab of Maliki uses the argument of al-Thalaq verse 4 as the legality of the marriage of minors.

\footnotetext{
${ }^{8}$ Al-'Asqalani, Fath al-Bāri Syarh Shahīh al-Bukhari, Juz IX (Beirut: Dar al-Kitab al-Islamiyyah), p.154

${ }^{9}$ Al-Sabuni, Mukhtasar Tafsīr Ibn Katsīr, Juz III, (Madinah: Dār al-Shābuniy, 1999), p. 233 
All four madhabs use the Hadith about marriage 'Aisha as the proof of the permissibility of the marriage of minors. ${ }^{10}$ Following are excerpts of the four madhabs statements regarding this issue:

- Madhab of Hanafi

The Prophet. married 'Aisyah r.a when she was just 6 years old, she lived in the same house with him when' Aisyah r.a was 9 years old. The household life between the two lasted only 9 years when the Prophet passed away the Divine presence in the year $11 \mathrm{H}$. The hadith about age "Aisha is evidence of the legality of the marriage of minors. ${ }^{11}$ The ability to marry saghir / saghirah sbased on the criteria of kafa'ah between the bride and groom through the payment of mitsil dowry. With a contract process that allows khiyar if adult later. ${ }^{12}$

- Madhab of Maliki

Maliki scholar Ulema stated: Abu Bakar al-Shiddiq married his daughter, is Aisyah r.a who was still a young girl at the age of 6 or 7 years. therefore, a father may marry his daughter who is still a child, both virgins and widows, although not yet reached menstrual age, and without his permission". ${ }^{13}$ The ability of guardians to marry off a child must be based on benefit. ${ }^{14}$

- Madhab of Syafici

Madhab of Syafi'i legalizes the saghir / saghirah marriage if it is carried out by a father or grandfather, and is not permitted if the khiyar is an adult. Al-Shafi'i mentioned 'Aisha was married by her father to the Apostle Saw. This shows that Abu Bakr (as a parent) has more right than 'Aisha (as a child) in marriage matters. Because, children aged 7 and 9 years certainly do not have adequate maturity (to make decisions). The marriage which is done rightfully must fulfill the kafa'ab element between the bride and groom. ${ }^{15}$

- Madhab of Hambali

Ibn Qudamah emphasizes that "against an independent girl, the father holds the authority of the marriage of his still-virgin daughter (without any disagreement by the scholars) on other terms. Basically, Abu Bakr married his daughter 'Aisha with the Prophet. when she was 6 years old. "Regarding the hadith about 'Aisha's marriage, it is understood that' Aisha's consent is not challenged, as the consent of the unborn child has not been revoked. 'Ali married his daughter Ummi Kaltsum with Umar Ibn Khatab when he was still a teenager. Ibn Qudamah further mentions the legality of minors in marriage, namely al-Thalaq letter $4 .{ }^{16}$

Only Ibn Syubramah had another view, where he saw the Prophet's marriage. with 'Aisyah as a child is her specialty. Ibn Syubramah's opinion reaped a lot of criticism from his fellow fuqaha'. Basically, no one among his friends or friends has confirmed that the Prophet's marriage practices. with 'Aisha is khususiyyah. ${ }^{17}$ In view of the Prophet's marriage. with 'Aisha A.a. who was a child,

${ }^{10}$ Al-Sarakhsi, Kitab al-Mabsut, Juz V, (Mesir: al-Sa'ādat, t.t), p. 212; Sayyid Sabiq, Fiqh al-Sunnah, Juz. II, (Madinah: al-Fath li 'Ilām al-'Arabiy, 1990), p.

11404 Al-Saraksi, Kitab al-Mabsut...,p. 212; Sayyid Sabiq, Fiqh al-Sunnah..., p. 404

${ }^{12}$ Ibn 'Abidīn, Hasyiyah Rad al-Muhtār, Juz III, (Beirut: Dar al-Fikr 1979), pp. 65-66

${ }^{13} \mathrm{Ibn}$ 'Abd Al-Barr, Al-Kafi, (Beirut: D ā r al-Kutub al-'Ilmiyyah, t.t), p. 231

${ }^{14}$ Ibn Rusyd, Bidāyah al-Mujtahid fi Nihāyah al-Muqtâìd. Juz II, (Semarang: Toha Putra, t.t), p.5

${ }^{15}$ Al-Syafi'i, al- Ümm..., p. 28-30

16 Ibn Qudamah, al-Mughnī..., pp.398-400

${ }^{17} \mathrm{Ibn}$ Hazm, al-Muhalla fi Syarh al-Mujalla bi al-Hujaj wa al-Atsar, (Yordania: Bait al-Afkar, t.t), p. 160 
contemporary Islamic jurists also held that it could not be used as a backup. Similarly, Joseph Hanafi in his book "Child Marriage Controversy Perspectives on Islamic Perspective, International Human Rights, and National Law". They argue that religion in principle does not explicitly prohibit minors, but never advocates it, especially when it is practiced without regard to the physical, mental, and rights dimensions of children. As for the historical marriage of the Prophet. with 'A'isha r.a positioned as an exception (exemption) and previllege (specialty) that promotes certain aims and wisdom in religion. ${ }^{18}$

\subsection{Possible Reinterpretations of the Age of Marriage}

\section{a. The Qur'an 'al-Nisa letter' verses 5-6}

"And do not give to those who are not yet perfect, the substance (of those in your power) whom God has made a source of life. give them shopping and clothing (from the produce) and say good words to them. And try the orphans until they are old enough to marry. Then if you think they've been clever (good at preserving property), then give them their property...."

This verse states that a guardian should test orphans as they reach the age of marriage; if they appear to have intelligence, then the wealth that has been under guardianship should be given to them. In that verse there is a description of the age of marriage. Thus, through a clear understanding of this verse, there is an age limit that one must go through before marriage. To read carefully the network is to test orphans before giving up their assets; not for the ability or the inability to marry. ${ }^{19}$ Basically, it should be practiced as it is, as long as there is no evidence to turn it around or prosecute it.

Although the basic premise of the above verse is the demand for Muslims to educate and treat orphans, but the Qur'anic guidelines can also apply to their own children. In the case of a child whose parents have been left behind, a foster parent is instructed to: (1) educate, (2) test their maturity "until they are married" before entrusting them with complete financial management. ${ }^{20}$ As Jalal al-Sayuthi says "Balaghu al-nikab" which is "they speak because they have dreamed of semen or are old enough to be fifteen years old according to Shaykh". ${ }^{21}$ Al-Mawardi added that baligh alone is not sufficient for a person to be given wealth, but must be accompanied by a second condition of maturity (rusyd). ${ }^{22}$ Al-rusyd means the ability to act appropriately. ${ }^{23}$

\section{b. Al-Qur'Aan surat al-Nisa 'verse 9}

"And let God fear those who leave behind them weak children, whom they are worried about (their welfare) ..."

Based on 'isyarah al-nas above, that children's education is very important to be able to live properly and independently in the future. They are feared weak in the fields of aqidah, worship, education, health and economy. Weaknesses in various sectors can lead to their lives that are not

\footnotetext{
${ }^{18}$ Yusuf Hanafi, Kontroversi Perkawinan Anak di Bawah Umur (Child Marriage) Perspektif Fikih Islam, HAM Internasional dan UU Nasional, (Bandung: Mandar Maju, 2011, p. 67

${ }_{19}$ Mukhsin Nyak Umar, Ushul Fiqh, (Banda Aceh: Ar-Raniry Press, 2008), p. 198

${ }^{20}$ Amir Syarifuddin, Pembaharuan Pemikiran dalam Hukum Islam, (Padang: Angkasa Raya, 1990), p. 114

${ }^{21}$ Al-Sayuti, Al-Mahalli, Tafsìr al-Jalālayn..., Juz I, p. 191

22 Al-Mawardi, Al-Hawi al-Kabir, Juz IX, (Beirut: Dar al-Fikr, 1994), p. 14

${ }^{23}$ According to the Syafi'i rusyd sect, his childhood was when he saw the good in his actions in matters of religion and property while in the Maliki sect in matters of property. See: Al-Sayuti, Al-Mahalli, Tafsir alJalālayn..., 191
} 
optimal in the future. Because of that Islam advocates a marriage for those who are already established in all aspects of life. Every bride needs to be tested first so that she is truly believed to be ready to settle down.

Interpretation of the verse is a form of reformulation of the provisions of the verse adapted to the demands of contemporary life, without prejudice to the principles and objectives of the Shari'a, where one of the five objectives of the Shari'a is to maintain offspring. Ahmad Rafiq stated, although the determination of the age limit is ijtihadiyyah, but the Qur'an surah al-Nisa 'verse 9 can be understood as a mandate not to leave future generations in a state of weakness and worry, one of which is by not marrying them when they are not ready, both physically and mentally. ${ }^{24}$

\section{c. Ibn Mas'ud's hadith}

"O young people, whoever among you has been able to get married, let him marry, because with marriage it is more to maintain eye sight and farj. And whoever is not able, he should fast ". (HR. Bukhari) ${ }^{25}$

The hadith of Ibn Mas'ud gives a suggestion regarding first, one is not allowed to be single forever; secondly, marriage can take place if someone is ready and able to provide $a l-b \bar{a}^{\prime} a b$; the third marriage aims to channel biological desires; fourth, for those who have not been able to shoulder the cost of living in a household, it is better to work on circumcision fasting, because by fasting he has a moral fortress facing the trials of life. ${ }^{26}$

According to the interpretation of fuqaba, the word syabāb, plural of syab, means "to move and be persistent". The meaning of syabāb is translated here as young people, those who have reached the age of 30 years. ${ }^{27}$ Abdul Gani Isa said that it was not an age-restricted necessity because in it there was no khitab (statement), either in the form of the khitab al-talab which had to be followed or the khitab al-tark to be abandoned. ${ }^{28}$ However $a$-ba'áb contained in the hadith of Ibn Mas'ud has the meaning of mu'nah (the cost of marriage) and is wath' (capable). Nawawi stated that there was an ulama's climax about the meaning of $a l-b a^{\prime} a{ }^{\prime} h .{ }^{29}$ The difference of opinion above shows that al-ba'ahb can mean wath'i and mu'nah, both of which are urgent in a marriage institution. The law provides for family obligations for the husband, based on the letter surah al-Thalaq verse 7 and the letter al-Baqarah verse 233 . Both verses can be understood dalalab-ibarah related to the obligation to provide for a household.

Besides material livelihood in the household, it is also important to consider the immaterial aspects for success in sailing a family ark. Amir Syarifuddin said "one of the conditions that must be fulfilled for men and women who will marry is that they have reached an appropriate age to get married". ${ }^{30}$ Implicitly, the Sharia requires that those who want to get married are truly prepared materially, physically, psychologically and know the meaning of a marriage. Not determined a

\footnotetext{
${ }^{24}$ Ahmad Rafiq dalam Yusuf Hanafi, Kontroversi Perkawinan Anak di Bawah Umur (Child Marriage)..., 45

${ }^{25}$ Al-'Asqalani, Fath al-Bāri..., p. 133

${ }^{26}$ Abdul Gani Isa, Beberapa Masalah Hukum Islam Menulusuri Paradigma Fiqih Kontemporer (Studi Beberapa Masalah Hukum Islam), (Banda Aceh: Ar-Raniry Press, 2009), p. 37

${ }^{27}$ Lois Ma'luf, Lois Ma'luf, Al-MunjÊd, (Beirut: Dar al-Masyrik, 2007), p. 360

${ }^{28}$ Abdul Gani Isa, Beberapa Masalah Hukum Islam, Menelusuri Paradigma Fiqih..., p. 37

${ }^{29}$ Al-'Asqalani, Fath al-Bār..., pp. 134-135

${ }^{30}$ Amir Syarifuddin, Hukum Perkawinan Islam di Indonesia, Antara Fiqh Munakahat dan Undang-Undang Perkawinan, (Jakarta: Prenada Media, 2006), p 66
} 
certain age in marriage is to give freedom to the people in accordance with the circumstances in the local area.

\subsection{Istimbat Law}

Age limitation in marriage has 'illat to achieve the maslahah target of the syar ' $i$, but there is still an element of damage which is to contain maslahah and mafsadah. If there are more problems then the illat can be accepted, because there is still a problem with the wisdom of the law. But if the mafsadah is bigger then suchillat must be rejected. If the maslahah and mudharah are the same, then the rule of law will disappear. ${ }^{31}$ The above description shows the dominance of mudharah that arises compared to the maslabah of the marriage of minors.

Acceleration of maturity achievement itself differs between men and women which is influenced by cultural environmental factors, the level of intelligence of a community, and several other factors. In line with the latest findings that individuals who live in the tropics (hot regions) reach the age of puberty earlier than those who live in cold regions. ${ }^{32}$ Using the minimum baligh / balighah limit offered by the fiqh of four madhabs to be able to carry out marriage still requires further study. Life now is very much different from ancient times, where in the past parents always watched the development and growth of their children even after having a family. With current civilization, relatively high urban patterns have resulted in inadequate parental control. The bride and groom are not ready for marriage in terms of various aspects, especially in the preparation of material as a basic need, and the leadership attitude in the household besides not being able to take care of all attitudes related to taklifi law and wadh'i as signs of life that must be maintained and maintained in various interactions in order to achieve a solid and intact household under the protection of Allah.

According to Undang-Undang Perkawinan (marriage law) Number 1 of 1974, article 7 paragraph (1) a person needs to get permission from parents to have a marriage if a man is still 19 years old and if a woman is 16 years old. That means, men and women whose age under these provisions are not allowed to carry out marriages. Provisions in article 7 paragraph (2) concerning the rules on the age limit for men or women who will carry out marriages become flexible or even disappear if the court gives a dispensation of marriage age so that the age limit becomes insignificant. Although men have reached the age of 19 years and for women who have reached the age of 16, both are still required to obtain permission from their parents if they are not yet 21 years of age Article 6 paragraph (2). This provision seems ambiguous, because it seems that marriage law adopts double standards. ${ }^{33}$

\section{Conclusion}

Based on the description and discussion previously, it can be concluded that the fiqh of four madhabss of principle does not in principle set the age for men and women to be married. They use the argument of surah al-Thalaq verse 4, the Hadith about the marriage of the Prophet. with 'Aisyah r.a who is still 6 or 7 years old. With regard to the postulates used by four madhabs, new readings can be made, firstly Surat al-Thalaq verse 4, said wa al-la' $i$ yabidna is understood to women who do not experience menstruation due to illness not minors. This understanding is

\footnotetext{
${ }^{31}$ Al-Ghazaliy, al-Mustashfa min 'Ilm al-'Ushul, Juz I, (Beirut: Dār al-Fikr, t.t). p 61

32 Ploss, Woman, dalam Yusuf Hanafi, Kontroversi Perkawinan Anak di Bawah Umur (Child Marriage).., pp. 55-56

${ }^{33}$ Syafiq Hasyim, Hal-hal yang Tak Terpikirkan Tentang Isu-isu Keperempuanan dalam Islam, (Bandung: Mizan, 2001), pp. $81-90$
} 
supported by Surah al-'Ahzab verse 49 about the unnecessary $i d d a b$ for women who have not been mixed. The second marriage hadith of the Prophet. with 'Aisha r.a at the age of 6 or 7 years occurred in Mecca before the tasyri period'. Related to the need to determine the minimum age of marriage can be used in the arguments of a number of verses of the Qur'an and the hadith, firstly Surat al-Nisa 'verses 5-6. This verse is understood in dalalah al-ibarah, namely the minimum age at marriage which applies not only to orphans; the second surah al-Nisa 'verse 9 dalalah al-ibarah is understood as a message not to leave future generations in a state of weakness and worry, one of which does not marry them when they are not ready physically or mentally; the three hadiths used, namely the hadith Ibn Mas'ud understood in al-nas dalalah al-nash that the prospective husband must have been able to provide the cost of marriage and wath ' $i$; the four hadiths about the need to ask permission of a girl / widow before marriage, this hadith is understood in the manner of dilalah al- isyarah namely the prospective wife is already baligh because a new permit is 'iktibar when someone has reached the age of baligh; the fifth wisdom of marriage is not found in shaghirah marriage. The Qur'an and the hadith explicitly require maturity as one of the requirements or the harmony of marriage, so that anyone who wants to get married should have maturity, both physically and mentally. The age of maturity between one climate and another, between one era and another is not always the same. In this case the experts may do ijtihad about the lowest ideal age for marriage.

\section{References}

Abdul Gani Isa, Beberapa Masalah Hukum Islam Menulusuri Paradigma Fiqih Kontemporer (Studi Beberapa Masalah Hukum Islam), (Banda Aceh: Ar-Raniry Press, 2009),

Al Qurtubi, al-Jāmi‘ li-'Abkam al-Qur'ān, Juz V, (Beirut:Dār al-Fikr, t.t.)

Al Yasa' Abubakar, Ushul Figh: Metodologi Hukum Islam (Paradigma Penalaran dan Penalaran Istishlahiyah), (Banda Aceh: Program Pascasarjana IAIN Ar-Raniry, 2011)

Al-'Asqalani, Fath al-Bāri Syarh Shahīh al-Bukhari, Juz IX (Beirut: Dar al-Kitab al-Islamiyyah), Al-Ghazaliy, al-Mustashfa min Tlm al-'Ushul, Juz I, (Beirut: Dār al-Fikr, t.t).

Al-Jaziri, Kitab al-Fiqh 'alā al-Madhähib al-'Arba'ah, Juz IV, (Mesir: Dar al-Manaar, 1999),

Al-Mawardi, Al-Hawi al-Kabir, Juz IX, (Beirut: Dar al-Fikr, 1994)

Al-Muslim, Shabih Muslim, Juz. I, (Beirut: Dār al-Kitab al-Ilmiyyah, t.t),

Al-Qurtubi, Al-jāmi' al-'Abkam al- Qur’ àn, Juz XVIII, (Beirut: Dār al-Kitab al-'Ilmiyyah, 1993)

Al-Sabuni, Mukhtasar Tafsìr Ibn Katsìr, Juz III, (Madinah: Dār al-Shābuniy, 1999),

Al-Sarakhsi, Kitab al-Mabsut, Juz V, (Mesir: al-Sa'ādat, t.t),

Al-Sarakhsy, Usul al-Sarakhsy, Juz II, (Beirut: Dar al-Kutub al-Ilmiyyah, 1983),

Al-Syafici, al- Ümm Juz IV, (Beirut: Dar al-Kitab al-Ilmiyyah, 1993)

Amir Syarifuddin, Hukum Perkawinan Islam di Indonesia, Antara Fiqh Munakahat dan Undang-Undang

Perkawinan, (Jakarta: Prenada Media, 2006),

Amir Syarifuddin, Pembaharuan Pemikiran dalam Hukum Islam, (Padang: Angkasa Raya, 1990)

Hasan Ayyub, Fikih Keluarga, Terj. Abdul Ghoffar, (Fiqh al-'Usrah al-Muslimah), (Jakarta: Pustaka al-Kautsar)

Hasbi Ash-Shiddieqi, Pengantar Hukum Islam, Juz II, (Jakarta, Bulan Bintang, 1975)

Husein Muhammad, Fiqh Perempuan, Refleksi Kiai Atas Wacana Agama dan Gender, (Yokyakarta: LKIS Pelangi Aksara, 2007)

Ibn 'Abd Al-Barr, Al-Kafi, (Beirut: D ā r al-Kutub al-'Ilmiyyah, t.t)

Ibn 'Abidīn, Hasyiyah Rad al-Mubtär, Juz III, (Beirut: Dar al-Fikr 1979),

Ibn Hazm, al-Muballa fi Syarh al-Mujalla bi al-Hujaj wa al-Atsar, (Yordania: Bait al-Afkar, t.t), 
Ibn Rusyd, Bidāyah al-Mujtahid fi Nihāyah al-MuqtaIid. Juz II, (Semarang: Toha Putra, t.t)

Kompas, Edition 8 April 2001

Lois Ma'luf, Lois Ma'luf, Al-MunjêEd, (Beirut: Dar al-Masyrik, 2007),

Muh Zuhri, Hukum Islam dalam Lintasan Sejarah, (Jakarta: Rajagrafindo Persada,1996), hal. 14; A Mun'in Sirry, Sejarah Fiqih Islam, ( Jakarta: Risalah Gusti, 1995),

Muhammad Fauzi Adhim, Indabnya Pernikahn Dini, (Jakarta: Gema Insani Press),

Muhammad Fu'ad Abd al-Bāqi, al-Lu'lu' wa al-Marjan, Juz III, (t.t.p: Dār al-Fikr, t.t)

Muhammad Khatib al-Syarbayni, Mughnì al-Mubtāj, (Beirut: Dār al-Fikr, 1995)

Muhibbuththabary, Usia Nikah dalam Pernikahan, Tinjauan Terhadap Pemikiran Hukum Islam di Indonesia, Vol. VIII, No. 2, Banda Aceh: Jurnal Islam Futura IAIN Ar-Raniry, 2009,

Mukhsin Nyak Umar, Ushul Figh, (Banda Aceh: Ar-Raniry Press, 2008)

Ploss, Woman, dalam Yusuf Hanafi, Kontroversi Perkawinan Anak di Bawah Umur (Child Marriage)

Satria Effendi, Ushul Fiqh, (Jakarta; Prenada Media, 2005)

Sayyid Sabiq, Fiqh al-Sunnah, Juz. II, (Madinah: al-Fath li 'Ilām al-'Arabiy, 1990),

Syafiq Hasyim, Hal-hal yang Tak Terpikirkan Tentang Isu-isu Keperempuanan dalam Islam, (Bandung: Mizan, 2001)

Wahbah al-Zuhayli, al-Fiqh al-Islämi wa Adillatuh, Juz IV, (Beirut: Dār al-Fikr, 1989)

Yusuf Hanafi, Kontroversi Perkawinan Anak di Bawah Umur (Child Marriage) Perspektif Fikih Islam, HAM Internasional dan UU Nasional, (Bandung: Mandar Maju, 2011

Yusuf Qaradhawi, Fiqh Kontemporer, translated by As'ad Yasin, Hada al-Islām Fatāwa Mu'â̂irah, Juz II 